\title{
Breeding of Cory's shearwater Calonectris borealis on Selvagem Grande and beneficial effects of removal of invasive mammals
}

\author{
F. Zino, M. Biscoito and A. BuCKLE
}

\begin{abstract}
The largest colony of Cory's shearwater Calonectris borealis nests on the island of Selvagem Grande in the north-eastern Atlantic. In 2002, a programme of eradication was conducted to remove two alien invasive mammals, the house mouse Mus musculus and European rabbit Oryctolagus cuniculus. Preliminary studies recorded beneficial effects of the eradications for a variety of plant and animal species, including Cory's shearwater. We recorded fledging rates of shearwaters for 1982-2001, prior to the eradication, and for 2002-2020, after the eradication, from two quadrats, each containing 134-329 nest sites. Although there was annual fluctuation in fledging rates in the quadrats, the mean rate of $40.74 \pm$ SD 3.92 fledglings per 100 nest sites for the two quadrats combined prior to the eradication of mammals increased significantly, to $52.88 \pm$ SD 5.03 per 100 nest sites, after the eradications. Because the two mammals were removed synchronously it is difficult to know which factors depressed fledging of Cory's shearwaters on Selvagem Grande. However, the predatory behaviour of house mice on other oceanic islands, and the fact that increased fledging was seen soon after the eradications occurred, suggest predation by house mice on shearwater hatchlings was the main cause of losses.
\end{abstract}

Keywords Alien invasive species, Calonectris borealis, Cory's shearwater, European rabbit, house mouse, Mus musculus, Oryctolagus cuniculus, Selvagem Grande

\section{Introduction}

'The Cory's shearwater Calonectris borealis colony on the 1 Portuguese island of Selvagem Grande has been the subject of study since the first scientific expedition to the island in 1963 (Pickering \& Maul, 1965). Although categorized on the IUCN Red List as Least Concern (BirdLife

F. ZINO (Corresponding author, (D) orcid.org/0000-0001-9309-0786) Freira Conservation Project, Rua Dr. Pita 7, 9000-089 Funchal, Madeira, Portugal. E-mail fzino@netmadeira.com

M. Biscoito (D orcid.org/0000-0002-9347-0823) Museu de História Natural do Funchal, Madeira, Portugal

A. BUCKLE (D orcid.org/0000-0002-5449-9279) School of Biological Sciences, The University of Reading, Reading, UK

Received 19 January 2021. Revision requested 6 April 2021.

Accepted 5 May 2021. First published online 28 October 2021.
International, 2018), Cory's shearwater is a Species of European Conservation Concern, category 2 (concentrated in Europe) with a threat status of depleted (BirdLife International, 2017). The Selvagem Grande population has been estimated to be 29,450 breeding pairs and therefore comprises the largest breeding colony of this seabird (Granadeiro et al., 2006). This is considerably less than the 130,000-150,000 breeding pairs formerly believed to have bred on the island (Mougin \& Mougin, 2000). The decline was caused by intensive culling of chicks and adults for meat, oil and feathers by local fishermen (Zino, 1985). To halt this culling, Paul A. Zino (father of FZ) bought the culling rights in 1967 and built a small house on the island to support scientific study. This effectively turned the island into a wardened private nature reserve until it was made an official Nature Reserve by the Portuguese government in 1971, but wardening ceased and illegal killing resumed, with the indiscriminate slaughter in 1976 resulting in an estimated 8,00o breeding pairs in 1980 (Zino, 1985). Since 1981, Selvagem Grande has been wardened by Madeiran institutions, including latterly the Instituto das Florestas e Conservação da Natureza (previously Parque Natural da Madeira). This has resulted in an increase in the population of Cory's shearwaters of c. 5\% per annum (Granadeiro et al., 2006).

The breeding biology of Cory's shearwater on Selvagem Grande is well studied (Zino, 1971; Zino et al., 1987, 1991; Mougin \& Jouanin, 1997; Mougin, 2000; Mougin et al., 2000; Mougin \& Mougin, 2000) and the breeding cycle is consistent from year to year. Birds start to return to the island in early February, with numbers increasing through to March. Mating occurs mainly in April and egg-laying during late May-mid June (Zino et al., 1987; Thibault et al., 1997). Immediately after the female lays the single egg, the male takes over incubation but thereafter they incubate alternately. Incubation is 54 days and eggs hatch mid July-early August (Zino, 1971; Zino et al., 1987). Parent birds remain at the nest for 3-4 days after hatching, leaving chicks at risk of predation thereafter by the Madeiran wall lizard Teira dugesii selvagensis (Matias et al., 2009), yellowlegged gull Larus michahellis and, formerly, house mice Mus musculus (F. Zino, pers. obs., 1963-2008). Adults make long journeys, as far as the coast of Mauritania (F. Zino, unpubl. data, 1996), to obtain food for their young. Chicks reach maximum weight in September, which is when culling previously occurred, some reaching almost double their adult 
weight. The chicks fledge in late October, c. 100 days after hatching (Zino et al., 1987).

The island had harboured populations of two alien invasive mammals (Howald et al., 2015), the house mouse Mus musculus and the European rabbit Oryctolagus cuniculus. Depredations inflicted on nesting seabirds and the floras of oceanic islands by these species have been described (Courchamp et al., 2003). A successful campaign of eradication was conducted against these two species by staff of the Parque Natural da Madeira in the latter part of 2002 and early 2003 (Oliveira et al., 2010). Baits containing 50 ppm brodifacoum, a potent anticoagulant rodenticide, were applied from c. 17,00o baiting points established on a $12.5 \times 12.5 \mathrm{~m}$ grid across the entire island, where the terrain permitted. Bait was also applied by hand on steep slopes and cliffs where bait stations could not be placed. Preliminary studies documented the beneficial effect of this action on invertebrate and plant communities and on populations of Berthelot's pipit Anthus berthelotti berthelotti and two reptiles, T. dugesii selvagensis and Tarentola bischoffi (Oliveira et al., 2010). However, an objective of the eradication programme was also the protection of the internationally important breeding populations of five pelagic seabirds: Cory's shearwater Calonectris borealis, Bulwer's petrel Bulweria bulwerii, Barolo (or Macaronesian) shearwater Puffinus baroli (also referred to as Puffinus iherminieri or Puffinus iherminieri baroli), white-faced storm-petrel Pelagodroma marina hypoleuca and band-rumped stormpetrel Hydrobates castro. Of these, Cory's shearwater is the most amenable to study because the terrain and locations of nests of the other species in unstable sandy substrates make population monitoring more difficult (Granadeiro et al., 2006). The island's Cory's shearwaters, however, build nests in accessible areas and are tractable to handling during laying and incubation without risk of nest desertion (Zino, 1971; Zino et al., 1987).

A long-term examination of the breeding biology of Cory's shearwater on Selvagem Grande began in 1971 with the establishment of two quadrats (named $A B C D$ and EFGH; Zino, 1971; Zino et al., 2008), and nests have been monitored ever since. This study has provided an opportunity to observe changes in the breeding biology of Cory's shearwater of Selvagem Grande over a period of almost 50 years. Monitoring of the benefits of island renovation programmes is generally lacking because logistical difficulties may prevent return to the islands concerned and scarce resources are preferably spent on extending programmes to additional islands (Brooke et al., 2007). However, the study of Cory's shearwater on Selvagem Grande has permitted an assessment of the beneficial impacts of the eradication of invasive mammals on this species.

A preliminary assessment, published 4 years after the eradications, showed an increase of $23-47 \%$ in the fledging rate of Cory's shearwater in the two quadrats (Zino et al.,
2008). The eradication began around the time of hatching in 2002 and fledging rates began to increase in that year. This suggests that the effects of the invasive mammals were on hatchlings and developing chicks, rather than by disturbance of pairing, courtship, nest-building and egg-laying or direct predation of eggs. It was, and still is, impossible to know which biological processes had been causing depression of fledging rates prior to the eradication, but it seems likely it was predation of newly-hatched chicks by house mice (Cuthbert \& Hilton, 2004).

Study of the breeding Cory's shearwater in the two quadrats has continued since the assessment of Zino et al. (2008), and there are therefore now 19 years of data since the removal of rabbits and house mice in 2002. Here we provide these additional data on fledging rates and confirmation of the beneficial impacts of the removal of rabbits and mice on this population of Cory's shearwater and, probably, on the other, smaller and thus more vulnerable seabirds on the island.

\section{Study area}

The 270 ha Selvagem Grande is the largest island in an archipelago in the north-eastern Atlantic, between Madeira, $300 \mathrm{~km}$ to the north, and the Canaries, $150 \mathrm{~km}$ to the south. The geology is volcanic, with a semi-arid ecosystem (Mata et al., 2010). Approximately 150 ha of the island is a sandy plateau used for nesting by burrowing seabirds, with other areas comprising boulder-strewn slopes, with gradients from gentle to precipitous, and there are sea cliffs in the north rising to c. $100 \mathrm{~m}$ along $25 \%$ of the coastline.

The island, and neighbouring Selvagem Pequena and Ilhéu de Fora, are protected under Portuguese Law as a Strict Nature Reserve, and by international regulations concerning their bird species (Grimmett \& Jones, 1989; Costa et al., 2003; European Union, 2009), and administered by the Instituto das Florestas e Conservação da Natureza. Selvagem Grande is an important breeding location for five pelagic seabird Species of European Conservation Concern (Oliveira \& Menezes, 2004; BirdLife International, 2017).

The two study quadrats were established on opposite sides of the island (Fig. 1). Quadrat ABCD is c. $16 \times 140 \mathrm{~m}$ at Baía das Pardelas in the east, exposed to the north-east trade winds. Quadrat EFGH is c. $15 \times 100 \mathrm{~m}$, in the southwest below the lighthouse on Pico da Atalaia, and relatively sheltered. Both quadrats are in broken and rocky terrain, on slopes of $15-35 \%$.

\section{Methods}

Transport to the island was provided by Portuguese Naval patrol vessels but because of weather conditions and operational necessities, visits to the island were sometimes irregular and of variable duration. Nevertheless, in most 


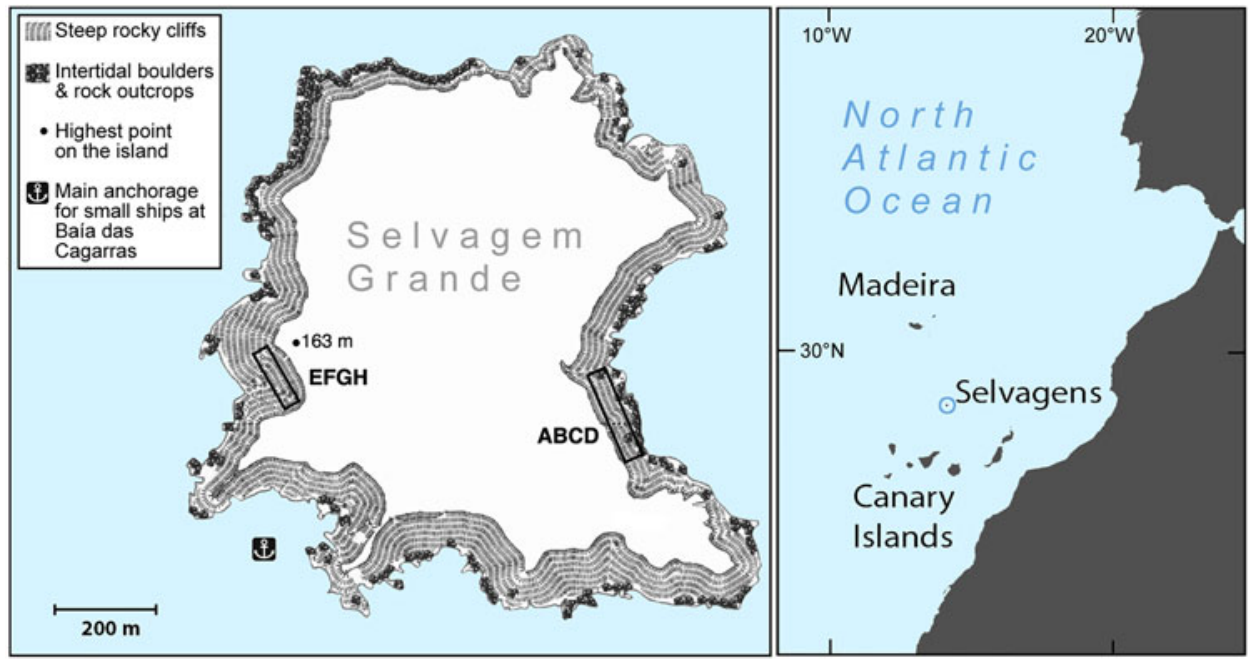

FIG. 1 Selvagem Grande, with the positions of the quadrats $\mathrm{ABCD}$ and EFGH used for monitoring the fledging of Cory's shearwater Calonectris borealis. years we made at least two visits, the first during egg-laying (late May-mid June) to locate and enumerate nests within the quadrats, and the second in either September or October so that chicks could be ringed prior to fledging. Study visits to the island became more consistent after 1982, when the navy started regular visits, and we therefore present the data from that year onwards. From 2009 onwards, we made sufficient visits to the island to obtain annual estimates of the per cent of nest failures by monitoring nests throughout the breeding period.

Principal data obtained from the quadrats annually were: (1) total number of nest sites, (2) total number of chicks that fledged from the nests found, and (3) per cent of nest sites from which a chick fledged (Table 1). Each nest was allocated a numeral that was marked nearby, and therefore nest sites were defined as any location in which eggs had been laid and previously enumerated (Table 1). All chicks were ringed.

Analysis was conducted using data from 14 years prior to eradication of the house mouse and European rabbit (1982-2001) and 19 following years (2002-2020) (Table 1). The main variable examined in the comparison of fledging before and after eradication was the per cent fledging rate. This was the per cent of all nests, both new nests found during the season in question and all nest sites previously occupied and enumerated, in a quadrat during that season that had a live chick on the final visit to the island. Some loss of chicks may occur after this visit and before fledging but, short of a catastrophic weather event, it is reasonable to assume the number is very small.

There were no nesting attempts at some of the enumerated nest sites. To accommodate this, and to derive a value for the per cent of nesting attempts that resulted in a fledged chick each season, a second variable was derived from the data using only those nests in which an egg was laid. These data, available for 12 years when more frequent visits made to the island (2009-2020), permitted assessment of the per cent of nests lost after pairing and laying.

\section{Results}

During 1982-2020, sufficient data for evaluation of the fledging rates of Cory's shearwater on Selvagem Grande were available for 33 years; 14 years prior to the 2002 eradication programme and 19 years after it. Table 1 gives the numbers of sites in the two quadrats where Cory's shearwaters had made nests and numbers of chicks that fledged in 1982-2020. In quadrat ABCD, the mean annual per cent fledging after eradication (52.6 \pm SD 6.4), was significantly greater than the mean before eradication $(37.0 \pm \mathrm{SD} 4.8$; $t=7.60, \mathrm{df}=31, \mathrm{P}=0.001$; Table 1 ) and likewise in quadrat $\mathrm{EFGH}$, mean fledging rate after eradication (53.4 \pm SD 4.8 ) was significantly greater than before $(45.3 \pm \mathrm{SD} 5.0 ; t=4.68$, $\mathrm{df}=31, \mathrm{P}=0.001$ ).

Combined values for fledging in the quadrats $(40.7 \pm \mathrm{SD}$ 3.9 fledglings per 100 nests before eradication and $52.9 \pm$ SD 5.0 afterwards) were also highly significantly different $(t=7.50, \mathrm{df}=31, \mathrm{P}=0.001)$. The mean number of nesting sites recorded in the quadrats after the eradication $(491.5 \pm$ SD 69.1) was significantly greater than the numbers recorded annually before the eradication (381.6 \pm SD 36.0; $t=5.41, \mathrm{df}=28, \mathrm{P}<0.001$; Fig. 2). Similarly, the mean number of chicks fledged after the removal of the alien invasive mammals (259.9 \pm SD 44.5), was significantly greater than the mean number fledged before the event (155.1 \pm SD 17.6; $t=8.31, \mathrm{df}=25, \mathrm{P}<0.001$; Fig. 3). Annual rates of increase for these parameters in the years after the eradication and relative to annual means prior to the event were $3.9 \%$ in numbers of nesting sites and $3.0 \%$ in numbers of fledged chicks. However, there was an increase in numbers of nests during pre-eradication years but not in numbers of fledged chicks (Table 1, Figs 2 \& 3 ).

All measured breeding parameters for Cory's shearwaters, both for quadrats separately and combined, showed highly significant increases after the removal of rabbits and house mice from Selvagem Grande. However, increases 
TABLE 1 The numbers of recorded nest sites and chicks of Cory's shearwater Calonectris borealis fledged and the per cent of recorded nests sites with fledged chicks for the two quadrats (ABCD, EFGH) on the island of Selvagem Grande (Fig. 1) for 1982-2020. Breeding attempts may not have occurred at some nest sites (see text for further details).

\begin{tabular}{|c|c|c|c|c|c|c|}
\hline \multirow[b]{2}{*}{ Year } & \multicolumn{3}{|l|}{$\mathrm{ABCD}$} & \multicolumn{3}{|l|}{ EFGH } \\
\hline & $\begin{array}{l}\text { Number of nest } \\
\text { sites recorded }\end{array}$ & $\begin{array}{l}\text { Number of } \\
\text { fledged chicks }\end{array}$ & $\begin{array}{l}\% \text { nest sites with } \\
\text { fledged chick }\end{array}$ & $\begin{array}{l}\text { Number of nest } \\
\text { sites recorded }\end{array}$ & $\begin{array}{l}\text { Number of } \\
\text { fledged chicks }\end{array}$ & $\begin{array}{l}\% \text { nest sites with } \\
\text { fledged chick }\end{array}$ \\
\hline \multicolumn{7}{|c|}{ Before mammal eradication } \\
\hline 1982 & 170 & 59 & 34.71 & 134 & 68 & 50.75 \\
\hline 1983 & 188 & 56 & 29.79 & 145 & 57 & 39.31 \\
\hline 1984 & 200 & 81 & 40.50 & 156 & 74 & 47.44 \\
\hline 1985 & 203 & 68 & 33.50 & 156 & 82 & 52.56 \\
\hline 1986 & 203 & 88 & 43.35 & 154 & 80 & 51.95 \\
\hline 1987 & 203 & 80 & 39.41 & 171 & 87 & 50.88 \\
\hline 1988 & 216 & 96 & 44.44 & 175 & 76 & 43.43 \\
\hline 1989 & 227 & 78 & 34.36 & 180 & 87 & 48.33 \\
\hline 1990 & 214 & 96 & 44.86 & 188 & 84 & 44.68 \\
\hline 1991 & 213 & 82 & 38.50 & 185 & 79 & 42.70 \\
\hline 1996 & 229 & 75 & 32.75 & 206 & 81 & 39.32 \\
\hline 1998 & 215 & 70 & 32.56 & 193 & 78 & 40.41 \\
\hline 1999 & 219 & 75 & 34.25 & 197 & 85 & 43.15 \\
\hline 2001 & 211 & 75 & 35.55 & 192 & 75 & 39.06 \\
\hline Mean $\pm S D$ & $207.93 \pm 15.41$ & $77.07 \pm 11.77$ & $37.04 \pm 4.82$ & $173.71 \pm 21.64$ & $78.07 \pm 8.07$ & $45.28 \pm 4.97$ \\
\hline \multicolumn{7}{|c|}{ After mammal eradication } \\
\hline 2002 & 208 & 110 & 52.88 & 200 & 99 & 49.50 \\
\hline 2003 & 206 & 130 & 63.11 & 189 & 115 & 60.85 \\
\hline 2004 & 208 & 93 & 44.71 & 189 & 108 & 57.14 \\
\hline 2005 & 232 & 150 & 64.66 & 207 & 123 & 59.42 \\
\hline 2006 & 234 & 101 & 43.16 & 202 & 104 & 51.49 \\
\hline 2007 & 241 & 123 & 51.04 & 213 & 113 & 53.05 \\
\hline 2008 & 249 & 131 & 52.61 & 199 & 124 & 62.31 \\
\hline 2009 & 251 & 134 & 53.39 & 217 & 106 & 48.85 \\
\hline 2010 & 250 & 122 & 48.80 & 225 & 110 & 48.89 \\
\hline 2011 & 269 & 124 & 46.10 & 229 & 118 & 51.53 \\
\hline 2012 & 261 & 143 & 54.79 & 212 & 115 & 54.25 \\
\hline 2013 & 279 & 125 & 44.80 & 235 & 103 & 43.83 \\
\hline 2014 & 290 & 129 & 44.48 & 177 & 93 & 52.54 \\
\hline 2015 & 296 & 159 & 53.72 & 225 & 125 & 55.56 \\
\hline 2016 & 312 & 157 & 50.32 & 261 & 136 & 52.11 \\
\hline 2017 & 316 & 196 & 62.03 & 265 & 157 & 59.25 \\
\hline 2018 & 317 & 186 & 58.68 & 268 & 146 & 54.48 \\
\hline 2019 & 324 & 179 & 55.25 & 276 & 139 & 50.36 \\
\hline 2020 & 329 & 178 & 54.10 & 278 & 134 & 48.20 \\
\hline Mean $\pm S D$ & $266.95 \pm 40.90$ & $140.53 \pm 28.90$ & $52.56 \pm 6.41$ & $224.58 \pm 31.35$ & $119.37 \pm 16.93$ & $53.35 \pm 4.83$ \\
\hline
\end{tabular}

were not uniform between the two quadrats. In their preliminary study, Zino et al. (2008) found that fledging prior to eradication in quadrat $\mathrm{ABCD}$ was lower than in quadrat EFGH. After eradication, fledging rates in both quadrats increased but the increase was greater in ABCD, so that fledging rates were similar in the two quadrats. These effects were again found in the larger data set that we present here. Mean annual fledging rate (fledglings per 100 nest sites) in quadrat EFGH prior to the removal of the mammals was, as given above, 45.3 $\pm 5.0(n=14)$, whereas in ABCD the rate was $37.0 \pm 4.8(n=14)$. These means are significantly different $(t=2.23, \mathrm{df}=26, \mathrm{P}=0.017)$. However, fledging rates after the eradication, $52.6 \pm 6.4(n=19)$ and $53.4 \pm 4.8$ $(n=19)$ in quadrats $A B C D$ and $E F G H$, respectively, did not differ significantly $(t=0.45, \mathrm{df}=34, \mathrm{P}=0.329)$. This indicated that recovery of shearwater breeding after eradication was more marked in quadrat ABCD than in EFGH.

Others who have studied breeding of Cory's shearwater on Selvagem Grande have estimated nest failure during the breeding season (Mougin et al., 1996; Granadeiro et al., 2006). From 2009, when the regularity of our visits increased, we were able to assess numbers of breeding attempts made by birds nesting in the quadrats. A breeding attempt was defined as the laying of an egg, irrespective of 

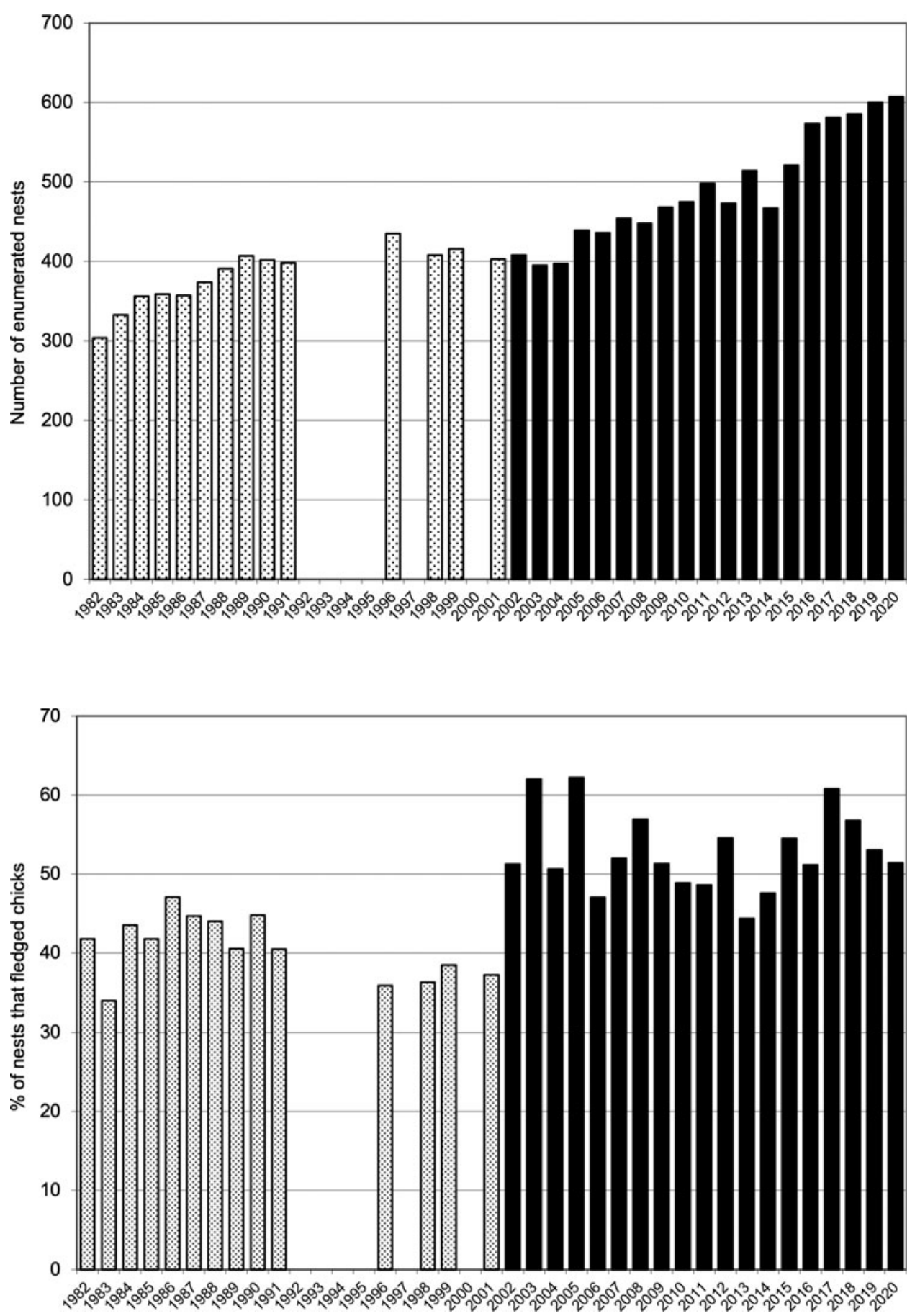

FIg. 2 The numbers of enumerated nest sites in which Cory's shearwaters had bred on Selvagem Grande, records for quadrats $\mathrm{ABCD}$ and $\mathrm{EFGH}$ combined, before the eradication of house mice and European rabbits 1982-2001 (stippled bars) and after eradication 2002-2020 (solid bars).
FIG. 3 The percentage of Cory's shearwater nest sites that fledged chicks on Selvagem Grande, records for quadrats $\mathrm{ABCD}$ and $\mathrm{EFGH}$ combined, before the eradication of house mice and European rabbits 1982-2001 (stippled bars) and after eradication 2002-2020 (solid bars). whether an individual or a pair of birds was present at a nest. The per cent of breeding attempts that resulted in a fledged chick was in the range $53.9 \%$ (2014) to $76.1 \%$ (2012) (Table 2) for the combined values for the two quadrats, with a mean for all years of $63.5 \%$. Thus, the average rate of nest failures in the two quadrats for $2009-2020$ was $36.5 \%$. Nest failure did not differ significantly between the two quadrats $(t=0.679, \mathrm{df}=22, \mathrm{P}=0.252)$. During 2009-2020 an egg was laid in an average of $82.0 \%$ of enumerated nest sites in the two quadrats. The per cent of occupied sites varied from a minimum of $71.7 \%$ in 2012 to a maximum of $88.2 \%$ in 2014. Although there was no consistent pattern in per cent nest site occupancy during this period, the year with the highest per cent of occupied sites (2014) was also the year with the lowest fledging rate and the reverse was true in 2012.

\section{Discussion}

Brooke et al. (2018) emphasized the importance of pre- and post-eradication monitoring so that better strategies can be 
TABLE 2 The numbers of nesting attempts and the per cent of breeding attempts that were successful of Cory's shearwaters in the two quadrats (ABCE, EFGH) on the island of Selvagem Grande during 2009-2020. A nesting attempt was considered to have occurred when birds had paired and an egg was laid. Per cent of attempts successful is derived from the number of nesting attempts and the number of fledged chicks (Table 1). It is only during 2009-2020 that sufficient visits were made to the island to obtain these data (see text for further details).

\begin{tabular}{|c|c|c|c|c|c|c|}
\hline \multirow[b]{2}{*}{ Year } & \multicolumn{2}{|l|}{$\mathrm{ABCD}$} & \multicolumn{2}{|l|}{ EFGH } & \multicolumn{2}{|l|}{ Combined } \\
\hline & $\begin{array}{l}\text { Number of } \\
\text { nesting attempts }\end{array}$ & $\begin{array}{l}\% \text { attempts } \\
\text { successful }\end{array}$ & $\begin{array}{l}\text { Number of } \\
\text { nesting attempts }\end{array}$ & $\begin{array}{l}\% \text { attempts } \\
\text { successful }\end{array}$ & $\begin{array}{l}\text { Number of } \\
\text { nesting attempts }\end{array}$ & $\begin{array}{l}\text { \% attempts } \\
\text { successful }\end{array}$ \\
\hline 2009 & 167 & 80.24 & 146 & 72.60 & 384 & 62.50 \\
\hline 2010 & 217 & 56.22 & 177 & 62.15 & 394 & 58.88 \\
\hline 2011 & 217 & 57.14 & 183 & 64.48 & 400 & 60.50 \\
\hline 2012 & 183 & 78.14 & 156 & 73.72 & 339 & 76.11 \\
\hline 2013 & 212 & 58.96 & 178 & 57.87 & 390 & 58.46 \\
\hline 2014 & 224 & 57.59 & 188 & 49.47 & 412 & 53.88 \\
\hline 2015 & 237 & 67.09 & 192 & 65.10 & 429 & 66.20 \\
\hline 2016 & 264 & 59.47 & 221 & 61.54 & 485 & 60.41 \\
\hline 2017 & 269 & 72.86 & 224 & 70.09 & 493 & 71.60 \\
\hline 2018 & 264 & 70.45 & 229 & 63.76 & 493 & 67.34 \\
\hline 2019 & 277 & 64.62 & 242 & 57.44 & 519 & 61.27 \\
\hline 2020 & 264 & 67.42 & 214 & 62.62 & 478 & 65.27 \\
\hline Mean $\pm S D$ & $232.92 \pm 35.70$ & $65.85 \pm 8.31$ & $195.83 \pm 30.11$ & $63.40 \pm 6.78$ & $434.67 \pm 16.39$ & $63.54 \pm 6.13$ \\
\hline
\end{tabular}

developed for the management of alien invasive vertebrates and the benefits of eradication programmes, challenged by some on ethical grounds (Howald et al., 2015), can be justified. The 39-year data set (1982-2020) for the fledging of Cory's shearwater chicks on Selvagem Grande has provided an unparalleled opportunity to investigate the biological benefits of mammal eradication on an island.

The beneficial effect of the eradications on Cory's shearwater is clear from the data presented here (Table 1, Figs $1 \& 2$ ). However, because two mammal species, the European rabbit and the house mouse, were removed from the island simultaneously we are unable to separate the impacts of the two species prior to their eradication. The best evidence that house mice rather than rabbits had the greatest influence on fledging rates comes from the observation that increased nest productivity occurred in 2002, even before eradication had been completed. The first bait application took place during 8-20 August 2002 (Oliveira et al., 2010), and would have removed the majority of both mammal populations quickly. This was the peak of hatchling emergence and we conclude that it was the adverse impacts of house mice on hatchlings that depressed fledging rates before eradication. Such direct predation is a characteristic of house mouse rather than rabbit behaviour (Courchamp et al., 2003; Cuthbert \& Hilton, 2004) and research on other islands has elucidated the predatory behaviour of house mice where they inhabit seabird colonies (Cuthbert, 2004; Cuthbert \& Hilton, 2004; Wanless et al., 2007). Prior to eradication there were up to 300 house mice per ha on Selvagem Grande (Oliveira et al., 2010).

Recording the numbers of nests in each quadrat (Table 1), although either carried out or supervised by FZ, was potentially subject to some imprecision and stochasticity because finding and enumerating nests in the rough terrain requires diligence and skill, and also because of occasional uncertainty about whether nests at the boundaries of the quadrats fell within them. Therefore, the most reliable measure of the increase in breeding performance of Cory's shearwater on Selvagem Grande after the eradication is the per cent of nest sites that successfully fledged young (Table 1 ). This parameter is not affected by stochasticity related to decisions about nest locations. The observed increase in Cory's shearwater fledging rates was not uniform between the two quadrats. In the 14 years of records before eradication, a mean of only 37.0 nest sites per hundred fledged a chick in quadrat $\mathrm{ABCD}$, and in quadrat EFGH this value was significantly higher at 45.3. A count of all accessible nests across the island found that increases in the numbers of nests during 19852005 were greater on the south and east coasts $(6.1 \%$ per year), where EFGH is situated, than elsewhere (4.3\%) (Granadeiro et al., 2006). This suggests recruitment was lower in some parts of the island, particularly in the north, because there were fewer nesting cavities and, therefore, poorer breeding conditions. However, fledging rates in our two quadrats, although different prior to mammal removal, did not differ significantly afterwards. We suggest that the alien invasive mammals, in particular house mice, may have played a role in the variation in fledging rates in different parts of the island prior to eradication. Potential causes of this could be: (1) house mouse abundance may have differed, perhaps driven by the availability of food, water and harbourage, so there may have been more mice present in some areas, (2) less alternative food for house mice in some parts of the island, possibly affected by different microclimates and soil substrates, and mice in some areas 
therefore relied more on Cory's chicks for food, or (3) because the environment of Selvagem Grande is arid, liquids available as chicks emerge from egg membranes may have stimulated mice to attack chicks.

The Madeiran wall lizard also predates Cory's shearwater hatchlings on Selvagem Grande (Matias et al., 2009), and we also observed this species feeding on the carcases of chicks, more so after the mammal eradications, and occasionally attacking live chicks. Matias et al. (2009) studied 78 shearwater nests in 2006 and 153 in 2007, and recorded fledging rates of 71 and $73 \%$, respectively. Predation by lizards was responsible for $18.2-19.5 \%$ of nest failures and estimated to have caused a reduction in nest productivity of $5 \%$. Oliveira et al. (2010) showed that the island's population of the gecko T. bischoffi increased on Selvagem Grande as a result of the mammal eradications and it seems likely that the Madeiran wall lizard also benefited, probably by the removal of mice that may prey upon lizard eggs and young. Matias et al. (2009) concluded that the Cory's shearwater population could tolerate lizard predation, but their nests were more productive than those in our larger and long-term study of Cory's shearwater, even after the removal programme (Table 2). Thus, the increase in the fledging rates of Cory's shearwater apparently achieved by the removal of mice from Selvagem Grande may be partly offset by increased predation by lizards, whose population was itself released from mouse predation.

Since the culls of Cory's shearwaters (the last in 1967) and the illegal taking of adult and chicks thereafter, culminating in the events of 1976 , population recovery has gone through a number of stages. Mougin et al. (2000) recorded population growth of c. $30 \%$ per annum during 1980-1985, attributing this to the recruitment of subadults that had been in their first decade, and therefore at sea, during the 1976 slaughter. During 1985-1995, Mougin et al. (1996) estimated a slower population annual growth rate of c. 5\%. A census of breeding Cory's shearwaters on Selvagem Grande in 2005 (Granadeiro et al., 2006) estimated a population of 29,540 breeding pairs, giving an average annual population growth rate of $4.6 \%$ since the earlier estimate of 18,000 breeding pairs (Mougin et al., 1996). Granadeiro et al. (2006) estimated it would take the population 35 years to recover to its presumed level prior to the culls (c. 140,000 breeding pairs). It is likely that, so long as there are no new and unforeseen threats to Cory's shearwaters, the rate of population increase on Selvagem Grande will accelerate as a result of the significant increases in fledging rates that we report.

During 2009-2020, for which our data permit the estimation of nesting success, it is apparent that c. $35 \%$ of eggs laid in the two quadrats failed to produce a fledged chick (Table 2). This is similar to an estimate of egg loss during incubation of $32 \%$ (Mougin et al., 1996), obtained before mice and rabbits were removed. Granadeiro et al. (2006) recorded a loss of $25 \%$ of clutches during the 2005 breeding season, which was 3 years after eradication. The 12-year span of our data provides information on the annual variation in nest failure (Table 2). The highest was in quadrat EFGH in 2014, when $46 \%$ of nesting attempts failed, whereas in quadrat $\mathrm{ABCD}$ in 2009 the failure rate was only $20 \%$. Annual variations in nest failure are potentially caused by a range of factors, including: (1) predation by the Madeiran wall lizard, either a result of annual variation in the lizard population or in the availability of alternative food and water, (2) food availability for the adults at sea, and consequently feeding rates for chicks, and (3) adverse weather conditions on the island during the nesting period (heavy rain may occur in September and October, and juveniles are sometimes found either washed off their nests or interred in burrows by soil deposited by flood water). However, we do not know the relative importance of these three factors, nor even if they are the most important.

With a head-tail length of $60 \mathrm{~cm}$ and a mean female body weight of c. $750 \mathrm{~g}$, and c. $900 \mathrm{~g}$ for males, Cory's shearwater is the largest of the five seabirds nesting on Selvagem Grande and therefore may have been the species least affected by house mouse predation. It seems reasonable to assume, therefore, that emergence and fledging of smaller species, such as the band-rumped and white-faced storm-petrels, would have improved at a rate similar to that of Cory's shearwater. However, this remains speculative because there are no detailed studies of the other four species and potential predation by lizards is a confounding factor. We believe our long-term study provides encouragement to those involved in the management of alien invasive mammals elsewhere and incentive to those who conduct eradication programmes to monitor the impacts of this essential conservation work.

Acknowledgements We thank the Portuguese Navy for transportation, the Parque Natural da Madeira (now Instituto das Florestas e Conservação da Natureza) for permission to work on the island; the wardens, particularly Jaques da Mata and Carlos Santos, for their assistance with field work; Centro de Estudos de Migrações e Proteção de Aves (Instituto da Conservação da Natureza e das Florestas, Lisbon) for providing bird rings; Elizabeth A., wife of FZ, and their son Alexander and daughter Francesca, and a number of volunteers for help during visits and fieldwork; the University of Reading for funding the publication of the article; and two reviewers for their helpful and constructive comments.

Author contributions Fieldwork: FZ, the late P.A. Zino, MB; data analysis: the late Mike Hounsome, $\mathrm{AB}$; writing: $\mathrm{AB}$; revision: all authors.

\section{Conflict of interest None.}

Ethical standards During the long duration of the study the ethical standards applicable varied. Permission to handle and ring Cory's shearwaters on Selvagem Grande was initially granted by the Parque Natural da Madeira and latterly by the Instituto das Florestas e Conservação da Natureza. Ringing protocols applied were those provided by Centro de Estudos de Migrações e Proteção de Aves, the national ringing authority 
from the Instituto da Conservação da Natureza e das Florestas, which granted ringing licences to $\mathrm{FZ}$ and $\mathrm{MB}$. This research otherwise abided by the Oryx guidelines on ethical standards.

\section{References}

BirdLife International (2017) European Birds of Conservation Concern: Populations, Trends and National Responsibilities (eds A. Staneva \& I. Burfield). BirdLife International, Cambridge, UK.

BirdLife International (2018) Calonectris borealis. In The IUCN Red List of Threatened Species 2018. dx.doi.org/10.2305/IUCN.UK. 2018-2.RLTS.T22732244A132661794.en [accessed 8 June 2021].

Brooke, M. De L., Bonnaud, E., Dilley, B.J., Flint, E.N., Holmes, N.D., JonEs, H.P. et al. (2018) Enhancing the value of future island eradications needs improved understanding of past outcomes. Animal Conservation, 21, 19-20.

Brooke, M. De L., Hilton, G.M. \& Martins, T.L.F. (2007) Prioritizing the world's islands for vertebrate-eradication programmes. Animal Conservation, 380, 380-39o.

Costa, L., Nunes, M., Geraldes, P. \& Costa, H. (2003) Zonas Importantes para as Aves em Portugal. Sociedade Portuguesa para o Estudo das Aves, Lisbon, Portugal.

Courchamp, F., Chapuis, J.-L. \& Pascal, M. (2003) Mammal invaders on islands: impacts, control and control impact. Biological Review, 78, 347-383.

CUth BERT, R. (2004) Breeding biology and population estimate of the Atlantic petrel, Pterodroma incerta, and other burrowing petrels at Gough Island, South Atlantic Ocean. Emu, 104, 221-228.

Cuthiert, R. \& Hilton, G. (2004) Introduced house mice Mus musculus: a significant predator of endangered and endemic birds on Gough Island, South Atlantic Ocean? Biological Conservation, $117,483-489$.

European Union (2009) Directive 2009/147/EC of the European Parliament and of the Council, of 30 November 2009 on the conservation of wild birds. Official Journal of the European Union L 20/7. Brussels, Belgium, 26 January 2010.

Granadeiro, J.P., Dias, M.P., Rebelo, R., Santos, C.D. \& Catry, P. (2006) Numbers and populations trends of Cory's shearwater Calonectris diomedia at Selvagem Grande, Northeast Atlantic. Waterbirds, 29, 56-60.

Grimmett, R.F.A. \& Jones, T.A. (1989) Important Bird Areas in Europe. Technical Publication No. 9. International Council for Bird Preservation, Cambridge, UK.

Howald, G., Ross, J. \& Buckle, A.P. (2015) Rodent control and island conservation. In Rodent Pests and Their Control (eds A.P. Buckle \& R.H. Smith), pp. 366-396. CAB International, Wallingford, UK.

Mata, J., Ramalho, R., Matias, M.J., Fonseca, P.E., Martins, S. \& Prada, S. (2010) As Ilhas Selvagens. In Geologia das Ilhas dos Arquipélagos dos Açores e da Madeira e Geologia das Antigas Colónias (eds J.M. Cotelo Neiva, A. Riberiro, L. Mendes Victor, S. Noronha \& M. Magalhães Ramalho), pp. 29-35. Ciências Geológicas: Ensino, Investigação e sua História. Vol. III. Associação Portuguesa de Geólogos, Lisbon, Portugal.
Matias, R., Rubelo, R., Granadeiro, J.P. \& Catry, P. (2009) Predation by Madeiran wall lizards Teira dugesii on Cory's shearwater Calonectris diomedea hatchlings at Selvagem Grande, North Atlantic. Waterbirds, 32, 600-603.

Mougin, J.L. (2000) Pairing in the Cory's shearwater (Calonectris diomedea) of Selvagem Grande. Journal für Ornithologie, $141,319-326$.

Mougin, J.L., Granadeiro, J.P. \& Oliveira, P. (1996) L'evolution des effectifs des reproducteurs chez le puffin cendré Calonectris diomedea borealis de Selvagem Grande $\left(30^{\circ} 09^{\prime} \mathrm{N}\right.$, $15^{\circ} 52^{\prime}$ W) de 1992 à 1995. Boletim do Museu Municipal do Funchal, $48,171-178$.

Mougin, J.L. \& Jounin, C. (1997) Prospection alimentaire du puffin cendré Calonectris diomedea borealis de Selvagem Grande $\left(30^{\circ}\right.$ o $9^{\prime} \mathrm{N}$, $15^{\circ} 52^{\prime} \mathrm{W}$ ) pendant l'incubation, par télémétrie satellitaire. Comptes Rendus de l'Académie des Sciences, Paris, Séries III-Sciences de la Vie, $320,825-831$.

Mougin, J.L., Jounanin, C. \& Roux, F. (2000) Démographie du puffin cendré Calonectris diomedea de Selvagem Grande $\left(30^{\circ} 09^{\prime} \mathrm{N}\right.$, $15^{\circ} 52^{\prime}$ W). Revue d'Ecologie (la Terre et la Vie), 55, 275-29o.

Mougin, J.L. \& Mougin, M.C. (200o) L'evolution des effectifs des puffins cendrés Calonectris diomedea borealis de l'ile Selvagem Grande $\left(30^{\circ}\right.$ og $\left.{ }^{\prime} \mathrm{N}, 15^{\circ} 52^{\prime} \mathrm{W}\right)$ de 1995 à 1998. Boletim do Museu Municipal do Funchal, 52, 45-50.

Oliveira, P. \& Menezes, D. (2004) Birds of the Archipelago of Madeira. Funchal, Madeira, Portugal.

Oliveira, P., Menezes, D., Trout, R., Buckle, A., Geraldes, P. \& JEsus, J. (2010) Successful eradication of the European rabbit (Oryctolagus cuniculus) and house mouse (Mus musculus) from the island of Selvagem Grande (Macaronesian archipelago), in the Eastern Atlantic. Integrative Zoology, 1, 70-83.

Pickering, C.H.C. \& Maul, G.E. (1965) Scientific expedition to the Salvage Islands, July 1963. I. Introduction. Boletim do Museu Municipal do Funchal, 18, 129-131.

Thibault, J.-C., Bretagnolle, V. \& Rabouam, C. (1997) Calonectris diomedea Cory's shearwater. Birds of the Western Palaearctic, $1,75-98$.

Wanless, R.M., Angel, A., Cuthbert, R.J., Hilton, G.M. \& Ryan, P.G. (2007) Can predation by invasive mice drive seabird extinctions? Biological Letters, 3, 241-244.

Zino, P.A. (1971) The breeding of Cory's shearwater Calonectris diomedea on the Salvage Islands. Ibis, 113, 212-217.

Zino, P.A. (1985) Pequeno apontamento histórico sobre a caça das cagarras na Selvagem Grande e desenvolvimentos recentes nesta ilha. Bocagiana, 84, 1-14.

Zino, F., Biscoito, M., Blandy, E. \& Neves, H.C. (1991) Sexual dimorphism of Cory's shearwater Calonectris diomedea borealis on Selvagem Grande $\left(30^{\circ} 09^{\prime} \mathrm{N}, 15^{\circ} 52^{\prime} \mathrm{W}\right)$. Boletim do Museu Municipal do Funchal, 43, 301-309.

Zino, F., Hounsome, M.V., Buckle, A.P. \& Biscoito, M. (2008) Was the removal of rabbits and house mice from Selvagem Grande beneficial to the breeding of Cory's shearwaters Calonectris diomedea borealis? Oryx, 42, 151-154.

Zino, P.A., Zino, F., MAUL, T. \& Biscoito, M.J. (1987) The laying, incubation and fledging period of Cory's shearwater Calonectris diomedea borealis on Selvagem Grande in 1984. Ibis, 129, 393-398. 